\title{
Muscle Strength Training is Better than the Use of Growth Hormone (GH) in Bone Health of Wistar Rats
}

\author{
Entrenamiento de la Fuerza Muscular es Mejor que el Uso \\ de la Hormona del Crecimiento (GH) en Salud Ósea del Ratas Wistar
}

\begin{abstract}
Heliard Rodrigues dos Santos Caetano ${ }^{1}$; Robson Chacon Castoldi ${ }^{1,2}$; Éverton Alex Carvalho Zanuto ${ }^{1}$; Guilherme Akio Tamura Ozaki²; Thiago Alves Garcia $^{2}$; João Domingos Augusto dos Santos Pereira³ ; Carlos José Leopoldo Constantino ${ }^{3}$; Hermann BremerNeto $^{4}$; Ines Cristina Giometti ${ }^{4}$; Regina Celi Trindade Camargo ${ }^{5}$; José Carlos Silva Camargo Filho ${ }^{5} \&$ William Dias Belangero $^{2}$
\end{abstract}

CAETANO, H. R. S.; CASTOLDI, R. C.; ZANUTO, É. A. C.; OZAKI, G. A. T.; GARCIA, T. A.; PEREIRA, J. D. A. S.; CONSTANTINO, C. J. L.; BREMER-NETO, H.; GIOMETTI, I. C.; CAMARGO, R. C. T.; CAMARGO FILHO, J. C. S. \& BELANGERO, W. D. Muscle strength training is better than the use of growth hormone (GH) in bone health of Wistar rats. Int. J. Morphol., 37(1):104-110, 2019.

SUMMARY: The objective of this study was to evaluate the effects of growth hormone $(\mathrm{GH})$ and muscle strength training (ST) on the composition of bone tissue of Wistar rats through Raman spectroscopy. In total, 40 male rats were randomly distributed into four groups: $(\mathrm{N}=10)$ control $(\mathrm{C})$, control with the application of $\mathrm{GH}(\mathrm{GHC})$, strength training $(\mathrm{T})$, and strength training with the application of GH (GHT). The training consisted of four series of 10 water jumps, performed three times a week, with an overload corresponding to $50 \%$ of body weight and duration of four weeks. GH was applied at a dose of $0.2 \mathrm{IU} / \mathrm{kg}$ in each animal three times a week and every other day. After four weeks, the animals were euthanized and the right femurs collected for analysis of the bone structure. Raman spectroscopy (ER) was used to observe the following compounds from their respective bands: Calcium Carbonate-Triglycerides (fatty acids) $1073 \mathrm{~cm}^{-1}$, Collagen type I $509 \mathrm{~cm}^{-1}$, Bone-DNA Phosphate (Protein) $589 \mathrm{~cm}^{-1}$, Phosphate Phospholipids $1078 \mathrm{~cm}^{-1}$. For the statistical analysis, the Shapiro-Wilk and ANOVA One-Way variance analysis normality tests were performed, followed by the Tukey post-test. The results showed an increase in the concentrations of calcium carbonate-triglycerides (fatty acids), type I collagen, bone phosphate-DNA (protein), and phosphate phospholipids in all experimental groups, with or without ST and/or GH, But only the isolated training group differed significantly from the control group $(\mathrm{P}<0.05)$. It was concluded that all treatments could promote bone tissue gain, however, only the $\mathrm{T}$ group demonstrated a significant difference in the mineral compounds analyzed.

KEY WORDS: Swimming; Calcium carbonate; Collagen; Phosphate; Raman spectroscopy.

\section{INTRODUCTION}

Physical training (PT) has been used as an important tool for health promotion (Paes et al., 2015), as, with the increasing longevity of the world population, it is possible to observe the progression of the number of fractures caused by a decrease in bone mineral density Stolnicki \& Oliveira (2016). This can occur due to the impairment of tissue resistance, osteopenia, and osteoporosis (NIH Consensus Development Panel on Osteoporosis Prevention, Diagnosis, and Therapy, 2001).

In this sense, PT can promote the development of tissue, increasing its density, as well as the ratio of bone volume and trabecular thickness (Giordano et al., 2016). In addition, it can act on the release of growth hormone (GH), indirectly, causing hormonal release and, consequently, cellular growth (Lange et al., 2005). This hormone exerts an effect on osteoclasts and, more markedly, on osteoblasts, emphasizing the idea of a possible anabolic effect in the skeleton (Simpson et al., 2006).

GH secretion is essential for skeletal development and growth and maintenance of bone mass, since its action stimulates the growth of several tissues, such as muscle tissue, in addition to other important effects on the

\footnotetext{
${ }^{1}$ Graduation in Physical Education, Universidade do Oeste Paulista, Presidente Prudente, SP, Brazil.

${ }^{2}$ Faculty of Medical Sciences. Programa de Doutorado em Ciências da Cirurgia. Universidade Estadual de Campinas (UNICAMP), Campinas - SP, Brazil

${ }^{3}$ Department of Physics, Chemistry and Biology. Universidade Estadual Paulista "Júlio de Mesquita Filho" - UNESP - Presidente Prudente, SP, Brazil.

${ }^{4}$ Department of Functional Sciences, Universidade do Oeste Paulista - UNOESTE, Presidente Prudente - SP, Brazil.

${ }^{5}$ Department of Physiotherapy. Universidade Estadual Paulista "Júlio de Mesquita Filho" - UNESP, campus de Presidente Prudente, SP, Brazil.
} 
CAETANO, H. R. S.; CASTOLDI, R. C.; ZANUTO, É. A. C.; OZAKI, G. A. T.; GARCIA, T. A.; PEREIRA, J. D. A. S.; CONSTANTINO, C. J. L.; BREMER-NETO, H.; GIOMETTI, I. C.; CAMARGO, R. C. T.; CAMARGO FILHO, J. C. S. \& BELANGERO, W. D. Muscle strength training is better than the use of growth hormone (GH) in bone health of Wistar rats. Int. J. Morphol., 37(1):104-110, 2019.

longitudinal growth of children and adolescents. In addition, its deficiency in adults has been associated with bone loss and an increased risk of fractures (Pagnoncelli et al., 2014).

Being an anabolic substance, $\mathrm{GH}$ has been used in high-performance sports for the purpose of increasing physical performance and also in fitness centers for aesthetic purposes. However, the indiscriminate use of GH can have consequences for its users, since its action in the human body, especially in bone tissue, is not fully understood.

The possible forms of bone tissue analysis include Raman spectroscopy (RS) which is able to provide qualitative and quantitative information on organic compounds (Silveira et al., 2012). In addition, RS is a method of analysis that allows a real-time, non-destructive, and noninvasive diagnosis, obtaining measurements of cellular molecular structure, being a reliable option with regard to methods of analysis (Walton et al., 1970).

Considering the above, the objective of the present study was to evaluate the effect of growth hormone $(\mathrm{GH})$ and muscle strength training (ST) on the composition of bone tissue in wistar rats through raman spectroscopy.

\section{MATERIAL AND METHOD}

Animals. A total of 40 animals were used, males, 60 days old of the Wistar breed, from the Central vivarium at the Universidade do Oeste Paulista - UNOESTE. The rats were identified and kept in collective cages of 5 animals $(41 \times 34 \times 17.5 \mathrm{~cm})$, at an average temperature of $23^{\circ} \mathrm{C}$, light/ dark cycle of twelve hours, and with free access to water and feed. The present study was approved by the Committee on Ethics in the Use of Animals (CEUA) (protocol n 2626).

Experimental Protocols. The animals were divided into four groups $(\mathrm{N}=10)$ : control $(\mathrm{C})$, growth hormone (GHC), muscle strength training $(\mathrm{T})$, and muscle strength training with application of GH (GHT). The study period was five weeks, with one week of adaptation to the liquid medium (water) (1x10 jumps, 2x10 jumps, 3x10 jumps), with overload and duration progressively increased, as described by Manchado et al. (2006), and four weeks of physical training.

\section{Experimental Groups}

Group (C): the animals remained free in their cages with free access to water and food. However, with the intention of providing the same stress as the animals that received
GH (GHC and GHT groups), physiological solution (0.9\% sodium chloride) was administered instead of the hormone.

Group (GHC): the animals remained free in their cages with free access to water and food. In addition, $0.2 \mathrm{IU} / \mathrm{kg}$ of $\mathrm{GH}$ was injected subcutaneously in each animal three times a week on alternate days.

Group (T): the animals were submitted to an exercise protocol composed of four sets of 10 jumps, performed three times a week, in a cylindrical PVC container, specially modified for jumping in the water and with a depth appropriate to the length of the animals $(38 \mathrm{~cm})$. Between each set of jumps a 1 minute interval was established. The overload used corresponded to $50 \%$ of the body weight of each animal and was corrected weekly. The overload was accommodated in the anterior region of the thorax using a vest, as used by Chacon Castoldi et al. (2015). Similarly to group $\mathrm{C}$, the animals received physiological solution ( $0.9 \%$ sodium chloride) instead of GH.

Group (GHT): the animals performed compound exercise in a similar way to the protocol mentioned above, however, as in the case of the GH group, $0.2 \mathrm{IU} / \mathrm{kg}$ of $\mathrm{GH}$, instead of physiological solution, was administered to each animal. Immediately after application, the animals were induced to perform the training protocol.

Bone Tissue. At the end of the experimental period, all animals were anesthetized intraperitoneally with a dosage of $30 \mathrm{mg} / \mathrm{kg}$ body weight of Xylazine and $70 \mathrm{mg} / \mathrm{kg}$ body weight of Ketamine and euthanized by exsanguination (Paiva et al., 2005). The femur of the right hind limb was removed by means of a surgical procedure, after which it was immersed in physiological solution and stored at $-20^{\circ} \mathrm{C}$.

Raman Microscopy. Analysis of the bone structure was performed using a Renishaw micro-Raman spectrograph, model in-Via (Movasaghi et al., 2007). Alterations in the bands corresponding to the following compounds were measured: Calcium Carbonate - Triglycerides (fatty acids) $1073 \mathrm{~cm}^{-1}$, Collagen type I $509 \mathrm{~cm}^{-1}$, Bone Phosphate - DNA (Protein) $589 \mathrm{~cm}^{-1}$, Phosphate Phospholipids $1078 \mathrm{~cm}^{-1}$, according to the standardization developed by Movasaghi et al. (Table I).

A633 nm laser was used, with power in the sample of order of microwatt $(\mathrm{mW})$ and the diffraction grating was 1800 lines per $\mathrm{mm}$. The exposure time adopted was $30 \mathrm{~s}$ and the quantity of accumulations was equal to three.

Optical microscopy was obtained using a Leica microscope (DMLM series), coupled to the spectrograph, with an objective of 50x magnification. Three spectra were collected from each sample, totaling nine spectra per group. 
CAETANO, H. R. S.; CASTOLDI, R. C.; ZANUTO, É. A. C.; OZAKI, G. A. T.; GARCIA, T. A.; PEREIRA, J. D. A. S.; CONSTANTINO, C. J. L.; BREMER-NETO, H.; GIOMETTI, I. C.; CAMARGO, R. C. T.; CAMARGO FILHO, J. C. S. \& BELANGERO, W. D. Muscle strength training is better than the use of growth hormone (GH) in bone health of Wistar rats. Int. J. Morphol., 37(1):104-110, 2019

Statistical Analysis. After obtaining the data, the ShapiroWilk normality test was performed. As the data were confirmed as normal, the ANOVA One-Way variance test was carried out, followed by Tukey's post-test. All procedures adopted a significance level of $5 \%(\mathrm{p}<0.05)$. Calculations were performed with the application SPSS 22.0 for Windows ${ }^{\circledR}$.

\section{RESULTS}

The following mineral compounds were measured: Calcium Carbonate - Triglycerides (fatty acids) in the band area at $1073 \mathrm{~cm}^{-1}$; Collagen type I in the band area at 509 $\mathrm{cm}^{-1}$, Bone Phosphate - DNA (Protein) in the band area at $589 \mathrm{~cm}^{-1}$, and Phosphate Phospholipids in the band area at $1078 \mathrm{~cm}^{-1}$. These measurements demonstrated that Raman spectroscopy, through related vibrational bands, can be used to evaluate these mineral compounds (Figs. 1 and 2).

The results of the femoral diaphysis spectra, analyzed by Raman spectroscopy to verify the effects of strength training and $\mathrm{GH}$ application on the bone tissue of experimental animals, revealed that the vibrational bands with the bone tissue composition were different (Fig. 2).

When observing the values of the respective bands, it was possible to see that the $\mathrm{T}$ group demonstrated significant increases $(\mathrm{P}<0.05)$ in the values of all variables studied in relation to the $\mathrm{C}$ group (Calcium Carbonate - Triglycerides (fatty acids) Collagen type I, Bone Phosphate - DNA (Protein). In addition, it was verified that the GHC and GHT groups demonstrated an increase in these variables, however, without statistical significance (p>0.05) (Fig. 3).

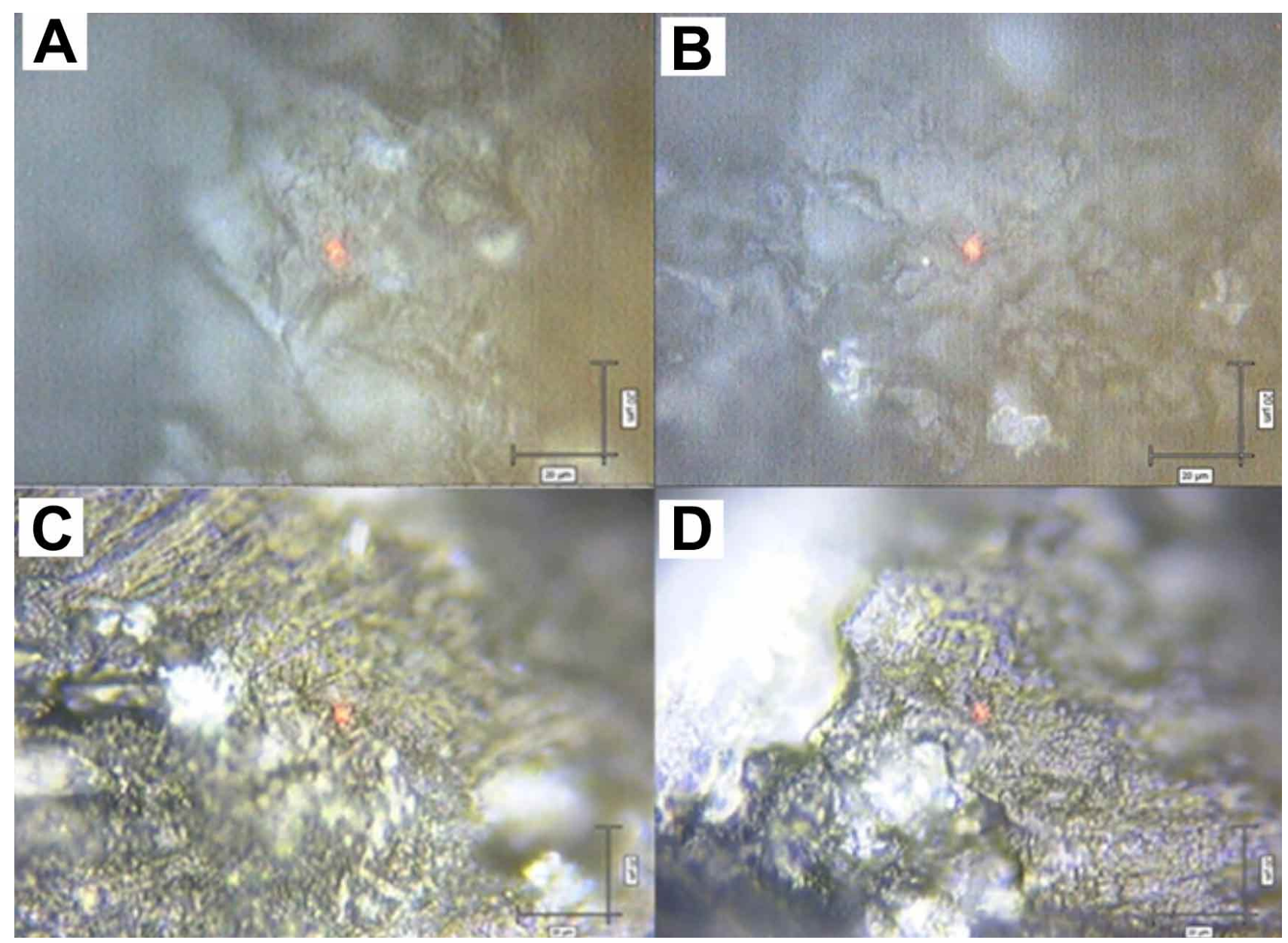

Fig. 1. Images of the femurs of Wistar rats in the following groups: Control (A); Control GH (B); Muscle Strength Training (C); Muscle Strength training with the use of GH (D). Photomicroscopy with a 50x magnification. Scale corresponding to $20 \mu \mathrm{m}$. 


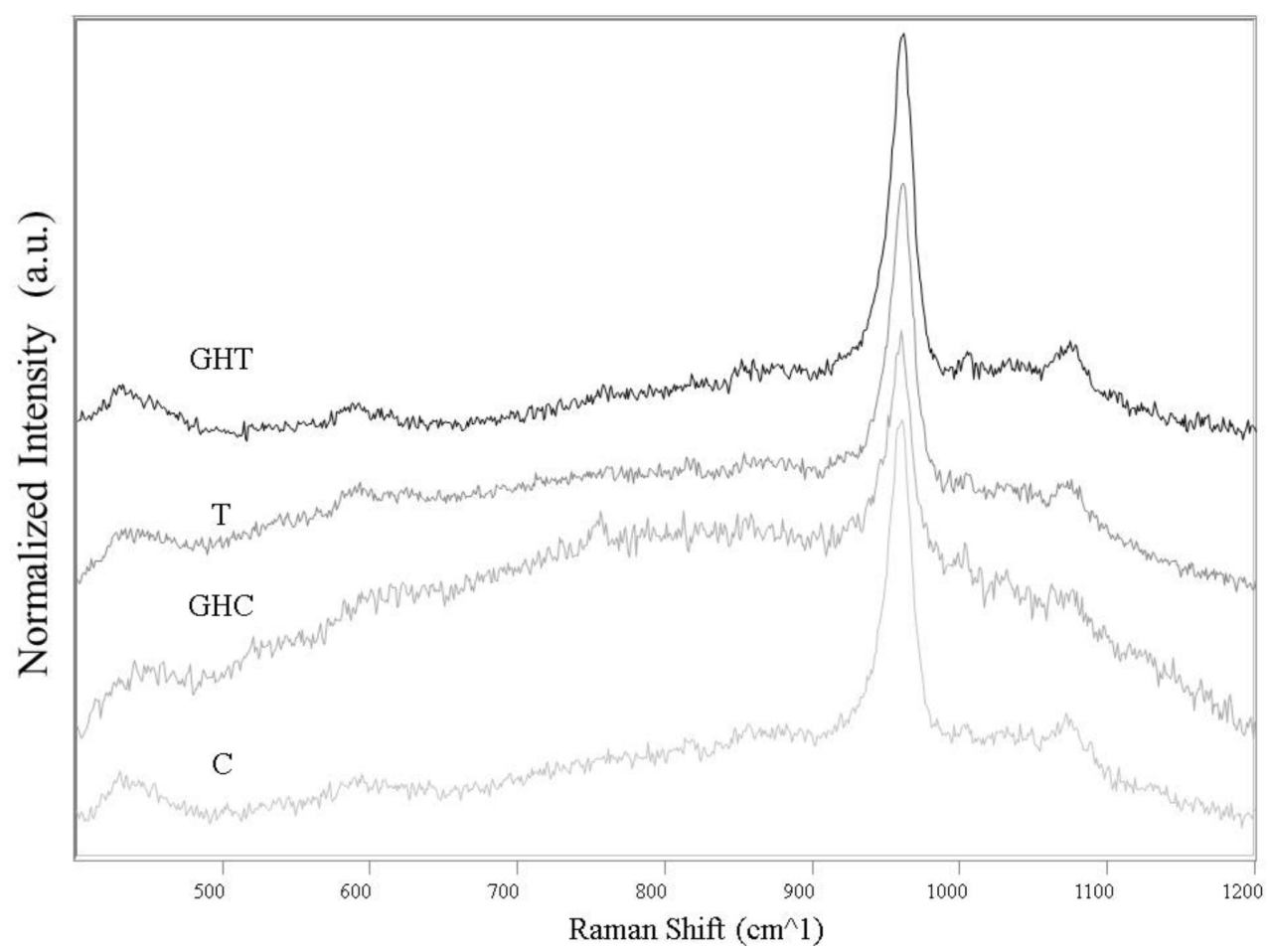

Fig. 2. Raman spectrum of bone $200-1200 \mathrm{~cm}-1$. The intensity is demonstrated in arbitrary units (a.u.). The intensity of $\mathrm{Y}=0$ (offset correction function) normalized for better visualization of the bands. A $633 \mathrm{~nm}$ laser was used.

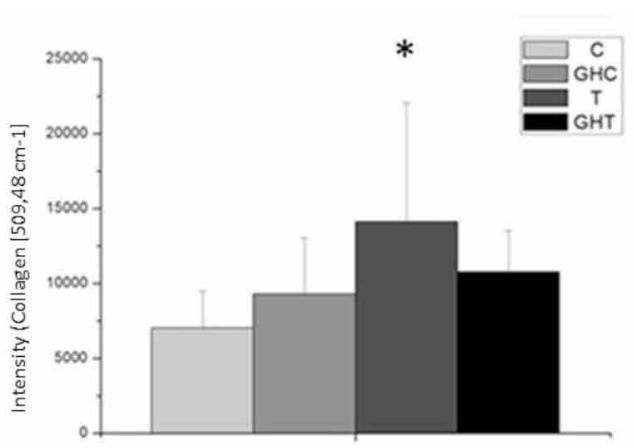

Animals Groups

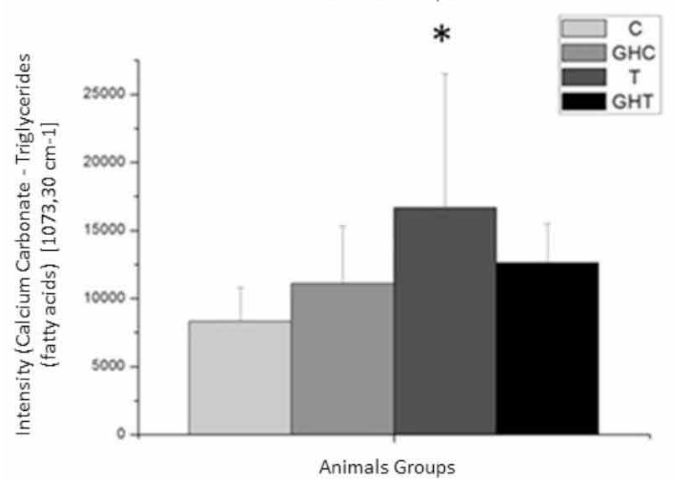

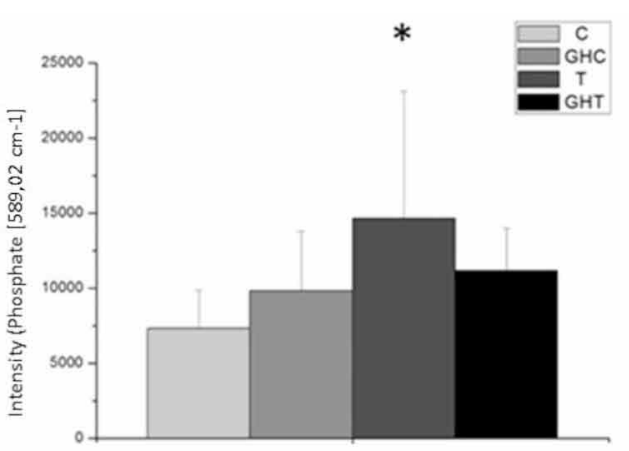

Animals Groups

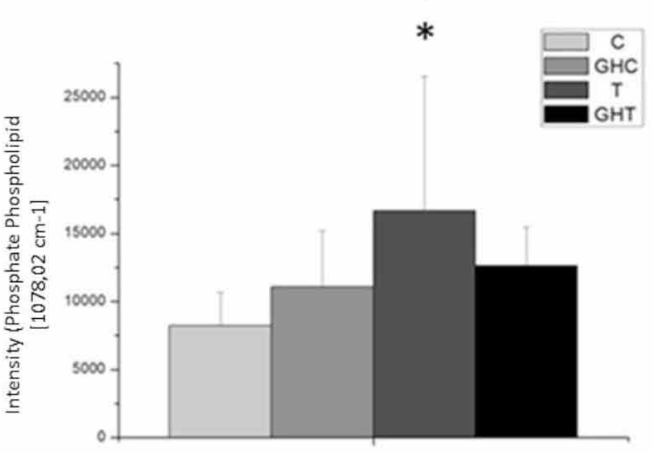

Animals Groups

Fig. 3. Analysis by Raman Spectroscopy of the quantification of the compounds Collagen Type I (A); Phosphate (B); Calcium Carbonate - Triglycerides (fatty acids) (C); and Phosphate Phospholipid (D) in the bone tissue of male animals. (*) Statistically significant difference between groups from the ANOVA test with Tukey Post-Test ( $\mathrm{p}<0.05)$. (\#): C different from T. 
CAETANO, H. R. S.; CASTOLDI, R. C.; ZANUTO, É. A. C.; OZAKI, G. A. T.; GARCIA, T. A.; PEREIRA, J. D. A. S.; CONSTANTINO, C. J. L.; BREMER-NETO, H.; GIOMETTI, I. C.; CAMARGO, R. C. T.; CAMARGO FILHO, J. C. S. \& BELANGERO, W. D. Muscle strength training is better than the use of growth hormone (GH) in bone health of Wistar rats. Int. J. Morphol., 37(1):104-110, 2019

\section{DISCUSSION}

Several methods have been used to study bone; however the majority of these methods are not sensitive enough to generate information at the molecular level (Currey, 2002). As it is a complex system, many variables can affect its composition, formation, strength, and properties (Allori et al., 2008). In this way, the method used in the present study was Raman spectroscopy (Movasaghi et al.).

It is probable the results obtained are due to the application of the strength training protocol, which can cause osteogenic stimuli, due to the increase in mechanical stress in the bones (Cadore et al., 2005). Furthermore, this stimulus caused by physical exercise apparently leads to increased bone resorption (Mottini et al., 2008).

It has been observed that practitioners of sports modalities with higher mechanical load present a greater quantity of bone tissue properties (Mottini et al.). Physical exercise programs have been widely used as part of the treatment and prevention of osteoporosis, since physical exercise induces an increase in mechanical load, which acts on the bone tissue due toexternal forces and muscle contractions. The increased mechanical load generates a tensile force, which promotes bone remodeling and an increase in bone mass (Mottini et al.).

Results similar to the present study were observed by Renno et al. (2007), who submitted rats to exercises for a period of eight weeks consisting of 4 sets of 10 jumps, which proved to be effective in increasing bone mass and strength. In the case of the present study, it was observed that the ST protocol (4 sets of 10 jumps) was adequate to increase the concentration of calcium carbonate triglycerides (fatty acids), as well as type I collagen and bone phosphate - DNA (protein), indicating increased tissue mineralization in response to training.

In another study using 16 repetitions of jumps with high and low loads for five weeks, a significant improvement in bone mineral density and cortical bone area was observed (Boudreaux et al., 2014). According to Mottini et al. and Cadore et al., the load imposed on the bone structure, mainly during physical exercise, produces an osteogenic effect.

Thus, it is probable that the exercise protocol applied in the present study was responsible for the increase in the mineral compounds analyzed. In an investigation using low intensity freestyle swimming as a protocol, for a period of four weeks, a decrease in bone mineral density was verified when compared to the results of the control group (Kim \& Park, 2005), reinforcing that the intensity of the exercises are key in the improvement of this parameter.

A study performed by Vasconcelos \& Santos-Júnior (2010) observed that the absence of stimuli on the bone tissue results in a decrease in the deposition of calcium, making it more fragile and weakened. Therefore, the stimulus generated by exercise is necessary to regulate the bone response, thereby providing better tissue calcification, growth, and remodeling.

In this sense, all biological tissue needs to receive stimuli to promote adaptations and development (Villafañe et al., 2013). The mechanical forces induced on this system through the sustentation of body weight and the practice of the physical exercise can exert an anabolic influence.

It is likely the increase in minerals in the $\mathrm{T}$ group was associated with $\mathrm{GH}$ secretion induced by exercise. This fact may contribute in the case of individuals with $\mathrm{GH}$ deficiency in early adulthood who present with decreased bone mineral density and a slight chance of fractures (Huang et al., 2002).

In the group in which the $\mathrm{GH}$ hormone was applied and the training protocol (GHT) performed, better results were observed in relation to the parameters analyzed in relation to the $\mathrm{GHC}$ and $\mathrm{C}$ groups, however this difference was not significant ( $\mathrm{p}<0.05$ ). The improvement in the GHT group results in relation to the control group may be due to the balance between reabsorption and formation of bone tissue, which is influenced by several factors, such as nutrition, hormonal activity, and physical exercise, among others (Hojan et al., 2013).

The physical training applied in this study, combined with the application of the GH hormone, resulted in a lower response in the parameters compared to the group which received training alone $(\mathrm{T})$. Although this difference was not significant $(\mathrm{p}<0.05)$, it implies that the application of GH may have inhibited its production, possibly through negative feedback.

The isolated application of the GH hormone also resulted in an improvement in the parameters analyzed, but again, this difference was not significant $(\mathrm{P}<0.05)$ in relation to the $\mathrm{C}$ group and/or the other groups of animals. $\mathrm{GH}$ has a fundamental role in bone health, since it exerts an effect on osteoclasts and more markedly on osteoblasts, creating the theoretical basis for its possible anabolic effect on the skeleton Tran et al. (2009). 
CAETANO, H. R. S.; CASTOLDI, R. C.; ZANUTO, É. A. C.; OZAKI, G. A. T.; GARCIA, T. A.; PEREIRA, J. D. A. S.; CONSTANTINO, C. J. L.; BREMER-NETO, H.; GIOMETTI, I. C.; CAMARGO, R. C. T.; CAMARGO FILHO, J. C. S. \& BELANGERO, W. D. Muscle strength training is better than the use of growth hormone (GH) in bone health of Wistar rats. Int. J. Morphol., 37(1):104-110, 2019.

One study observed that $\mathrm{GH}$ administered in a given region may stimulate growth of the width of the epiphysis cartilage and longitudinal bone growth (Wüster et al., 2001). This finding demonstrates the possible anabolic effect of $\mathrm{GH}$ in the animals used in the present study.

Finally, the present study collaborates with the literature in verifying the effects of the application of $\mathrm{GH}$ and the performance of an ST protocol. However, some limitations should be considered in this study, such as the hormonal dose applied, training protocol, and age of the animals. Future studies using different ages, training forms, hormonal dosages, supplementation, and forms of analysis may contribute to the findings described up to the present moment.

\section{CONCLUSIONS}

It is possible to conclude that the $\mathrm{T}$ group demonstrated greater mineralization of the compounds of the bone tissue: Calcium Carbonate - Triglycerides (fatty acids), Collagen type I, Bone Phosphate - DNA (Protein), and Phosphate Phospholipids when compared to the other groups of animals. In addition, the GHT and GHC groups, although presenting higher values than the $\mathrm{C}$ group, did not demonstrate significant differences.

\section{ACKNOWLEDGEMENTS}

The authors would like to thank the Coordination of Improvement in Higher Education - CAPES, for their assistance in the execution of the present work.

CAETANO, H. R. S.; CASTOLDI, R. C.; ZANUTO, É. A. C.; OZAKI, G. A. T.; GARCIA, T. A.; PEREIRA, J. D. A. S.; CONSTANTINO, C. J. L.; BREMER-NETO, H.; GIOMETTI, I. C.; CAMARgO, R. C. T.; CAMARGO FILHO, J. C. S. \& BELANGERO, W. D.Entrenamiento de la fuerza muscular es mejor que el uso de hormona del crecimiento $(\mathrm{GH})$ en salud ósea del ratas Wistar. Int. J. Morphol., 37(1):104-110, 2019.

RESUMEN: El objetivo del estudio fue avaluar el efecto de la aplicación de la hormona del crecimiento (GH) y entrenamiento de la fuerza muscular (EF) en la composición del tejido óseo de ratas Wistar a partir de la espectroscopía Raman. Fueron utilizadas 40 ratas machos distribuidas de forma aleatoria en cuatro grupos ( $n=10)$ : control (C), control y aplicación de GH (GHC), entrenamiento de la fuerza muscular (EF) y entrenamiento de la fuerza muscular y aplicación del GH (GHE). El entrenamiento fue consistió en cuatro series de 10 saltos acuáticos, realizados tres veces en la semana, con sobrecarga correspondiente a $50 \%$ de la masa corporal y durante cuatro semanas. El GH fue aplicado en la dosificación de 0,2 UI/kg en cada animal, tres veces en la semana y en días alternados. Después de cuatro semanas, los animales fueran eutanasiados y retirados los fémures derechos para un análisis de la estructura ósea. La espectroscopía Raman fue utilizada para observar los siguientes compuestos a partir de las respectivas bandas: Carbonato de Calcio-Triglicéridos (ácidos grasos) $1073 \mathrm{~cm}^{-1}$, Colágeno Tipo I $509 \mathrm{~cm}^{-1}$, Fosfato Óseo-DNA (Proteína) $589 \mathrm{~cm}$ ${ }^{1}$, Fosfato Fosfolípidos $1078 \mathrm{~cm}^{-1}$. Para el análisis estadístico, fueron realizadas las pruebas Shapiro-Wilk y el análisis de variancia ANOVA One-Way, seguida de test post hoc de Tukey. Los resultados revelaran aumento de la concentración de Carbonato de Calcio-Triglicéridos (ácidos grasos), Colágeno Tipo I, Fosfato ÓseoDNA (Proteína), Fosfato Fosfolípidos en todos los grupos experimentales, asociados o no a la realización del EF y/o aplicación del GH. Además, solamente el grupo EF mostró diferencia significativa del grupo $\mathrm{C}(\mathrm{p}<0,05)$. Es posible concluir que todos los tratamientos mostraran aumentos en el tejido óseo, sin embargo, solamente el grupo T demostró una diferencia significativa en los compuestos minerales analizados.

PALABRAS CLAVE: Natación; Carbonato de Calcio; Colágeno; Fosfato; Espectroscopia Raman.

\section{REFERENCES}

Allori, A. C.; Sailon, A. M.; Pan, J. H. \& Warren, S. M. Biological basis of bone formation, remodeling, and repair-part III: biomechanical forces. Tissue Eng. Part B Rev., 14(3):285-93, 2008.

Boudreaux, R. D.; Swift, J. M.; Gasier, H. G.; Wiggs, M. P.; Hogan, H. A.; Fluckey, J. D. \& Bloomfield, S. A. Increased resistance during jump exercise does not enhance cortical bone formation. Med. Sci. Sports Exerc., 46(5):982-9, 2014.

Cadore, E. L.; Brentano, M. A. \& Kruel, L. F. M. Effects of the physical activity on the bone mineral density and bone remodelation. Rev. Bras. Med. Esporte, 11(6):338e-44e, 2005.

Chacon Castoldi, R.; Rampazzo Teixeira, G.; de Mello Malheiro, O. C.; Trindade Camargo, R. C.; Dias Belangero, W. \& Silva Camargo Filho, J. C. Effects of 14 weeks resistance training on muscle tissue in Wistar rats. Int. J. Morphol., 33(2):446-51, 2015.

Currey, J. D. Bones. Structure and Mechanics. New Jersey, Princeton University Press, 2002.

Giordano, V.; Franco, J. S.; Koch, H. A.; Labronici, P. J.; Pires, R. E. \& Amaral, N. P. Age-related changes in bone architecture. Rev. Col. Bras. Cir., 43(4):276-85, 2016.

Hojan, K.; Milecki, P. \& Leszczynski, P. The impact of aerobic exercises on bone mineral density in breast cancer women during endocrine therapy. Poli. Orthop. Traumatol., 78:47-51, 2013.

Huang, T. H.; Yang, R. S.; Hsieh, S. S. \& Liu, S. H. Effects of caffeine and exercise on the development of bone: a densitometric and histomorphometric study in young Wistar rats. Bone, 30(1):293-9, 2002.

Kim, C. S. \& Park, D. H. Effects of chronic NH4Cl dosage and swimming exercise on bone metabolic turnover in rats. J. Physiol. Anthropol. Human Sci., 24(6):595-600, 2005.

Lange, U.; Kluge, A.; Strunk, J.; Teichmann, J. \& Bachmann, G. Ankylosing spondylitis and bone mineral density--what is the ideal tool for measurement? Rheumatol. Int., 26(2):115-20, 2005.

Manchado, F. B.; Gobatto, C. A.; Contarteze, R. V. L.; Papoti, M. \& de Mello, M. A. R. The maximal lactate steady state is ergometer-dependent in experimental model using rats. Rev. Bras. Med. Esporte., 12(5):25962, 2006. 
CAETANO, H. R. S.; CASTOLDI, R. C.; ZANUTO, É. A. C.; OZAKI, G. A. T.; GARCIA, T. A.; PEREIRA, J. D. A. S.; CONSTANTINO, C. J. L.; BREMER-NETO, H.; GIOMETTI, I. C.; CAMARGO, R. C. T.; CAMARGO FILHO, J. C. S. \& BELANGERO, W. D. Muscle strength training is better than the use of growth hormone (GH) in bone health of Wistar rats. Int. J. Morphol., 37(1):104-110, 2019

Mottini, D. U.; Cadore, E. L. \& Kruel, L. F. M. Efeitos do exercício na densidade mineral óssea. Motriz Rev. Educ. Fis., 14(1):85-95, 2008.

Movasaghi, Z.; Rehman, S. \& Rehman, I. U. Raman spectroscopy of biological tissues. Appl. Spectrosc. Rev., 42(5):493-541, 2007.

NIH Consensus Development Panel on Osteoporosis Prevention, Diagnosis, and Therapy. Osteoporosis prevention, diagnosis, and therapy. JAMA, 285(6):785-95, 2001.

Paes, S. T.; Marins, J. C. B. \& Andreazzi, A. E. Efeitos metabólicos do exercício físico na obesidade infantil: uma visão atual. Rev. Paul. Pediatr., 33(1):122-9, 2015.

Pagnoncelli, R. M.; Gerzson, A. S.; Camilotti, R. S.; Jasper, J. \& Böing, F. Hormônio do crescimento humano e a perspectiva futura em Odontologia. Rev. Fac. Odontol. U. P. F., 19(3):379-83, 2014.

Paiva, F. P.; Maffili, V. V. \& Santos, A. C. S. Curso de Manipulação de Animais de Laboratório. Salvador, Ministério de Saúde, FIOCRUZ, 2005.

Renno, A. C. M.; Faganello, F. R.; Moura, F. M.; dos Santos, N. S. A.; Tirico, R. P.; Bossini, P. S.; Zuanon, J. A.; Neto, C. B. \& Parizotto, N. A. The effects of a progressive loading exercise program on femoral physical properties and strength of osteopenic rats. Acta Ortop. Bras., 15(5):276-9, 2007.

Silveira, L. Jr.; Silveira, F. L.; Bodanese, B.; Zângaro, R. A. \& Pacheco, M. T. Discriminating model for diagnosis of basal cell carcinoma and melanoma in vitro based on the Raman spectra of selected biochemicals. J. Biomed. Opt., 17(7):077003, 2012.

Simpson, A. H.; Mills, L. \& Noble, B. The role of growth factors and related agents in accelerating fracture healing. J. Bone Joint Surg. Br., 88(6):701-5, 2006.

Stolnicki, B. \& Oliveira, L. G. Para que a primeira fratura seja a última. Rev. Bras. Ortop., 51(2):121-6, 2016.

Tran, G. T.; Pagkalos, J.; Tsiridis, E.; Narvani, A. A.; Heliotis, M.; Mantalaris, A. \& Tsiridis, E. Growth hormone: does it have a therapeutic role in fracture healing? Expert Opin. Investig. Drugs, 18(7):887-911, 2009.

Vasconcelos, A. P. T. \& Santos-Júnior, F. F. U. Alterações na densidade óssea pós-imobilização em ratos. Saúde Diálogo, 1:59-65, 2010.

Villafañe, J. H.; Cleland, J. A. \& Fernández-de-Las-Peñas, C. The effectiveness of a manual therapy and exercise protocol in patients with thumb carpometacarpal osteoarthritis: a randomized controlled trial. $J$. Orthop. Sports Phys. Ther., 43(4):204-13, 2013.

Walton, A. G.; Deveney, M. J. \& Koenig, J. L. Raman spectroscopy of calcified tissue. Calcif. Tissue Res., 6(2):162-7, 1970.

Wüster, C.; Abs, R.; Bengtsson, B. A.; Bennmarker, H.; Feldt-Rasmussen, U.; Hernberg-Ståhl, E.; Monson, J. P.; Westberg, B.; Wilton, P. \& KIMS Study Group and the KIMS International Board. Pharmacia \& Upjohn International Metabolic Database. The influence of growth hormone deficiency, growth hormone replacement therapy, and other aspects of hypopituitarism on fracture rate and bone mineral density. J. Bone Miner. Res., 16(2):398-405, 2001.
Corresponding author:

Robson Chacon Castoldi

Universidade do Oeste Paulista - UNOESTE

Departamento de Educação Física

Sala 231B, Bloco B3

Campus II, Rodovia Raposo Tavares Km 572

Bairro Limoeiro, CEP 19067-175

Presidente Prudente - SP

BRAZIL

\section{E-mail. castoldi@unoeste.br}

Received: 18-08-2018

Accepted: 26-11-2018 